\title{
Analisis Proses Berpikir Siswa dalam Memecahkan Masalah Matematika Berdasarkan Langkah-Langkah Bransford dan Stein Ditinjau dari Adversity Quotient
}

\author{
Avissa Purnama Yanti ${ }^{1}$ Muhamad Syazali ${ }^{2}$
}

1,2IAIN Raden Intan Lampung; avissapy88@gmail.com

\begin{abstract}
The thinking process of each student varies in solving mathematical problems. Their responses are different there is a surrender, try and there is unyielding. One of the factors that influence it is Adversity Quotient ( $A Q)$, which is a person's ability to respond to a challenge in his life to achieve success. Therefore, this study aims to describe the thinking process of students of MAN I Bandar Lampung based on Adversity Quotient (AQ) type climbers, campers and quitters in solving mathematical problems based on Bransford and Stein theories on equations and quadratic functions. This research is a qualitative descriptive research. Research subjects were determined through purposive sampling, and this research was conducted in class X MIA 4 MAN I Bandar Lampung with subject of 6 students divided into 3 groups. The first group consisted of 2 students of type climbers, the second group consisted of 2 students of campers, and the third group consisted of 2 students of type quitters. To determine the type of Adversity Quotient (AQ) of the subject to be selected, the ARP test is used. The data collection technique in this study uses the test method, unstructured interview method conducted on selected subjects and documentation method. Data analysis techniques through data reduction, data presentation, and conclusions. Written test result data is analyzed based on indicators that meet conceptual, semiconceptual, and computational thinking processes. The technique of data validity is done by using triangulation technique comparing data of test result and interview result to subject of climbers, campers and quitters. Based on the data analysis results obtained that the subject with the type Adversity Quotient (AQ) each has a different thinking process. Subjects with type climbers tend to have a conceptual thinking process in solving mathematical problems based on Bransford and Stein theories. Subjects with type campers tend to have a semiconceptual thinking process in solving mathematical problems based on Bransford and Stein theories, and subjects with type quitters in solving problems based on Bransford and Stein theories tend to have a computational thinking process.
\end{abstract}

Keywords: Adversity Quotient; Bransford and Stein; Thinking Process

\begin{abstract}
Abstrak
Proses berpikir setiap siswa berbeda-beda dalam memecahkan masalah matematika. Respon mereka pun berbeda-beda ada yang menyerah, berusaha dan ada yang pantang menyerah. Salah satu faktor yang mempengaruhinya adalah Adversity Quotient ( $A Q$ ), yaitu kemampuan seseorang dalam merespon suatu tantangan dalam kehidupannya untuk mencapai keberhasilan. Oleh karena itu, penelitian ini bertujuan untuk mendiskripsikan proses berpikir
\end{abstract}


siswa MAN I Bandar Lampung berdasarkan Adversity Quotient (AQ) bertipe climbers, campers dan quitters dalam memecahkan masalah matematika berdasarkan teori Bransford dan Stein pada materi persamaan dan fungsi kuadrat. Penelitian ini merupakan penelitian deskriptif kualitatif. Subjek penelitian ditentukan melalui purposive sampling, dan penelitian inidilakukan di kelas X MIA 4 MAN I Bandar Lampung dengan subjek berjumlah 6 siswa yang dibagi menjadi 3 kelompok. Kelompok pertama terdiri dari 2 siswa bertipe climbers, kelompok kedua terdiri dari 2 siswa bertipe campers, dan kelompok ketiga terdiri dari 2 siswa bertipe quitters. Untuk menentukan tipe Adversity Quotient (AQ) dari subjek yang akan dipilih, digunakan tes ARP.Teknik pengumpulan data pada penelitian ini menggunakan metode tes, metode wawancara tak terstruktur yang dilakukan kepada subjek yang telah terpilih dan metode dokumentasi. Teknik analis is data melalui reduksi data, penyajian data, dan penarikan kesimpulan. Data hasil tes tertulis dianalisis berdasarkan indikator-indikator yang memenuhi proses berpikir konseptual, semikonseptual, dan komputasional. Teknik keabsahan data dilakukan dengan menggunakan triangulasi teknik yang membandingkan data hasil tes tertulis dan hasil wawancara terhadap subjek climbers, campers dan quitters. Berdasarkan hasil analisis data diperoleh bahwa subjek dengan tipe Adversity Quotient ( $A Q$ ) masing-masing memiliki proses berpikir yang berbeda. Subjek dengan tipe climbers cenderung mempunyai proses berpikir konseptual dalam menyelesaikan masalah matematika berdasarkan teori Bransford dan Stein. Subjek dengan tipe campers cenderung mempunyai proses berpikir semikonseptual dalam menyelesaikan masalah matematika berdasarkan teori Bransford dan Stein, dan subjek dengan tipe quitters dalam menyelesaikan masalah berdasarkan teori Bransford dan Stein cenderung memiliki proses berpikir komputasional.

Kata Kunci: Adversity Quotient; Bransford dan Stein; Proses Berpikir.

\section{PENDAHULUAN}

Pembelajaran matematika adalah pembelajaran yang lebih menekankan pada pemecahan masalah matematika. Memecahkan suatu masalah merupakan suatu aktifitas dasar bagi manusia. Kenyataan menunjukkan, sebagian besar kehidupan manusia berhadapan dengan masalah-masalah sehingga perlu mencari penyelesaiannya. Berbicara mengenai masalah matematika, Lencher mendeskripsikan sebagai soal matematika yang strategi penyelesaiannya tidak langsung terlihat sehingga dalam penyelesaiannya memerlukan pengetahuan, keterampilan dan pemahaman yang telah dipelajari sebelumnya (Hartono, 2014). Pembelajaran melalui pemecahan masalah (learning via problem solving) merupakan tujuan dan kendaraan untuk memahami konsep matematika.

Proses berpikir pada pemecahan masalah matematika yang dilakukan siswa terlihat dari runtutan penyelasaian masalah tersebut. Salah satu runtutan atau langkah pemecahan masalah yang digunakan adalah langkah-langkah model Bransfors dan Stein. Pemecahan masalah yang dikenalkan oleh Bransford dan Stein (1993) adalah IDEAL problem solving yaitu model penyelesaian masalah yang mampu meningkatkan kemampuan berpikir dan meningkatkan keterampilan dalam proses penyelesaian masalah (J \& Stein, 1993).Metode pemecahan masalah model Bransfors dan Stein merupakan kegiatan pembelajaran dengan cara mengajarkan siswa menyelesaikan masalah-masalah untuk meningkatkan pemahaman terhadap suatu materi baik secara konseptual maupun prosedural. IDEAL problem solving didasarkan pada penelitian dan hasil karya dari ahli-ahli sebelumnya dalam penyelesaian 
masalah seperti Max Wertheimer, George Polya, Alan Newell dan Herbert Simon (Susiana, 2010).

Menurut Bransfors dan Stein, IDEAL problem solving didesain untuk membantu mengidentifikasi dan memahami bagian-bagian yang berbeda dari penyelesaian masalah, masing-masing huruf melambangkan komponen penting dalam proses penyelesaian masalah. IDEAL adalah singkatan dari I-Identify problem, D-Define goal, E-Explore possible strategies, $A$ Anticipate outcomes and act, L-Look back dan (Susiana, 2010). Penjelasan terhadap 5 tahap dalam IDEAL sebagai berikut di bawah ini:

\section{Mengidentifikasikan masalah (Identify problem)}

Langkah pertama dari IDEAL adalah secara sengaja (Intentionally) berusaha untuk mengidentifikasi (Identify) masalah dan menjadikannya sebagai kesempatan (opportunities) untuk melakukan sesuatu yang kreatif. Kemampuan untuk mengidentifikasi keberadaan masalah adalah satu karateristik penting untuk menunjang keberhasilan penyelesaian masalah. Jika masalah tidak diidentifikasi maka strategi yang mungkin digunakan tidak akan dapat ditemukan.

2. Menentukan tujuan (Define goal)

Langkah kedua dari IDEAL adalah mengembangkan (Develop) pemahaman dari masalah yang telah diidentifikasi dan berusaha menentukan (Define) tujuan. Menentukan tujuan berbeda dengan mengidentifikasi masalah. Perbedaan dalam penentuan tujuan dapat menjadi penyebab yang sangat kuat terhadap kemampuan seseorang memahami masalah, berpikir dan menyelesaikan masalah. Tujuan yang berbeda membuat orang mengeksporasi strategi yang berbeda untuk menyelesaikan masalah.

3. Mengeksplorasi strategi yang mungkin (Explore possible strategies)

Langkah ketiga dari IDEAL adalah mengeksplorasi (Explore) strategi yang mungkin dan mengevaluasi (Evaluate) kemungkinan strategi tersebut sesuai dengan tujuan yang telah ditetapkan.

\section{Mengantisipasi hasil dan bertindak (Anticipate outcomes and act)}

Langkah keempat dari IDEAL adalah mengantisipasi (Anticipate) hasil dan bertindak (Act). Ketika sebuah strategi dipilih, maka mengantisipasi kemungkinan hasil dan kemudian bertindak pada strategi yang dipilih. Mengantisipasi hasil yang akan berguna dari hal-hal akan disesali di kemudian hari.

\section{Melihat dan belajar (Look back and learn)}

Langkah terakhir dari IDEAL adalah melihat (Look) akibat yang nyata dari strategi yang digunakan dan belajar (Learn) dari pengalaman yang didapat.

(Susiana, 2010)

Berpikir selalu berhubungan dengan masalah-masalah yang timbul dari masa kini, masa lampau dan mungkin masalah-masalah yang belum terjadi. Proses pemecahan masalah itu disebut proses berpikir (Ahmadi, 2009) .Berpikir itu merupakan proses yang "dialektis" artinya selama kita berpikir, pikiran kita dalam keadaan tanya jawab, untuk dapat meletakkan hubungan pengetahuan kita. Dalam berpikir kita memerlukan alat yaitu akal (ratio) (Ahmadi \& Widodo Supriyono, Psikologi Belajar, 2013). Berpikir merupakan aktivitas psikis yang intensional, dan terjadi apabila seorang menjumpai problema (masalah), dengan demikian dalam berpikir itu seorang menghubungkan pengertian satu dengan yang lainnya dalam 
rangka mendapatkan pemecahan persoalan yang dihadapi. Pengertian itu merupakan bahan atau materi yang digunakan dalam proses berpikir (Ahmadi, 2009).

Langkah-langkah proses berpikir sebagai berikut: (1) pembentukan pengertian, yaitu adalah hasil proses berpikir yang merupakan rangkuman sifat-sifat pokok dari suatu barang atau kenyataan yang dinyatakan dalam suatu perkataan. (2) pembentukan pendapat, yaitu meletakkan hubungan antara dua buah pengertian atau lebih. dan (3) penarikan kesimpulan, yaitu sebagai hasil perbuatan akal untuk membentuk pendapat baru berdasarkan pendapatpendapat yang telah ada (Suryabrata, 2013).

Proses berpikir yang dimiliki siswa tidakselalu sama antara siswa yang satu dengan yang lainnya, dengan mengetahui proses berpikir siswa, guru dapat mengetahui kelemahan siswa serta dapat merancang pembelajaran yang sesuai dengan proses berpikir siswa. Banyak pendapat yang mengemukakan tentang jenis-jenis proses berpikir, salah satunya adalah pendapat Zuhri (1998) dalam jurnal Nasional. Zuhri (1998) mengungkapkan bahwa proses berpikir dibedakan menjadi tiga macam yakni proses berpikir konseptual, proses berpikir semikonsepual, dan proses berpikir komputasional (D, 1998). Proses berpikir konseptual merupakan cara berpikir siswa yang selalu menyelesaikan atau memecahakan masalah dengan menggunakan konsep yang dimiliki sesuai hasil pemahamannya selama ini. Proses berpikir semikonseptual merupakan cara berpikir siswa yang cenderung dalam menyelesaikan masalah menggunakan konsep tetapi kurang memahami konsep tersebut sehingga dalam menyelesaikan masalah dicampur dengan cara penyelesaian yang menggunakan intuisi dan proses berpikir komputasional merupakan cara berpikir yang pada umumnya dalam menyelesaikan masalah cenderung mengandalkan intuisi dan tidak menggunakan konsep (Retna, Mubarokah, \& Suhartatik, 2013).

Zuhri (1998) menentukan beberapa indikator untuk menelusuri masing-masing proses berpikir sebagai berikut:

1) Proses berpikir konseptual: mampu mengungkapkan apa yang diketahui dalam soal dengan kalimat sendiri, mampu mengungkapkan apa yang ditanya dalam soal dengan kalimat sendiri, dalam menjawab cenderung menggunakan konsep yang sudah dipelajari, dan mampu menyebutkan unsur-unsur konsep diselesaikan.

2) Proses berpikir semikonseptual: kurang dapat mengungkapkan apa yang diketahui dalam soal dengan kalimat sendiri, kurang mampu mengungkapkan dengan kalimat sendiri yang ditanya dalam soal, dalam menjawab cenderung menggunakan konsep yang sudah dipelajari walaupun tidak lengkap, tidak sepenuhnya mampu menjelaskan langkah yang ditempuh.

3) Proses berpikir komputasional: tidak dapat mengungkapkan apa yang diketahui dalam soal dengan kalimat sendiri, tidak mampu mengungkapkan dengan kalimat sendiri yang ditanya dallam soal, dalam menjawab cenderung lepas dari konsep yang sudah dipelajari, tidak mampu menjelaskan langkah-langkah yang ditempuh. $(D, 1998)$

Berdasarkan uraian di atas maka indikator yang digunakan dalam penelitian ini mengadaptasi dari indikator-indikator tersebut sebagai berikut : 
Tabel 1. Indikator Proses Berpikir

\begin{tabular}{|c|c|c|}
\hline Proses berpikir konseptual & $\begin{array}{l}\text { Proses berpikir } \\
\text { semikonseptual }\end{array}$ & $\begin{array}{l}\text { Proses berpikir } \\
\text { komputasional }\end{array}$ \\
\hline $\begin{array}{l}\text { - Siswa mampu menyatakan } \\
\text { apa yang diketahui dalam } \\
\text { soal dengan bahasa sendiri } \\
\text { atau mengubahnya dalam } \\
\text { kalimat matematika. (B.1.1) } \\
\text { - Siswa mampu menyatakan } \\
\text { apa yang ditanya dalam } \\
\text { soal dengan bahasa sendiri } \\
\text { atau mengubahnya dalam } \\
\text { kalimat matematika. (B.1.2) } \\
\text { - Siswa mampu membuat } \\
\text { rencana penyelesaian } \\
\text { dengan lengkap. (B.1.3) } \\
\text { - Siswa mampu menyatakan } \\
\text { langkah-langkah yang } \\
\text { ditempuh dalam } \\
\text { menyelesaikan soal } \\
\text { menggunakan konsep yang } \\
\text { pernah dipelajari. (B.1.4) } \\
\text { - Siswa mampu memeriksa } \\
\text { kembali kebenaran atau } \\
\text { mengoreksi kesalahan dari } \\
\text { setiap langkah } \\
\text { penyelesaian sehingga } \\
\text { diperoleh hasil yang benar. } \\
\text { (B.1.5) }\end{array}$ & 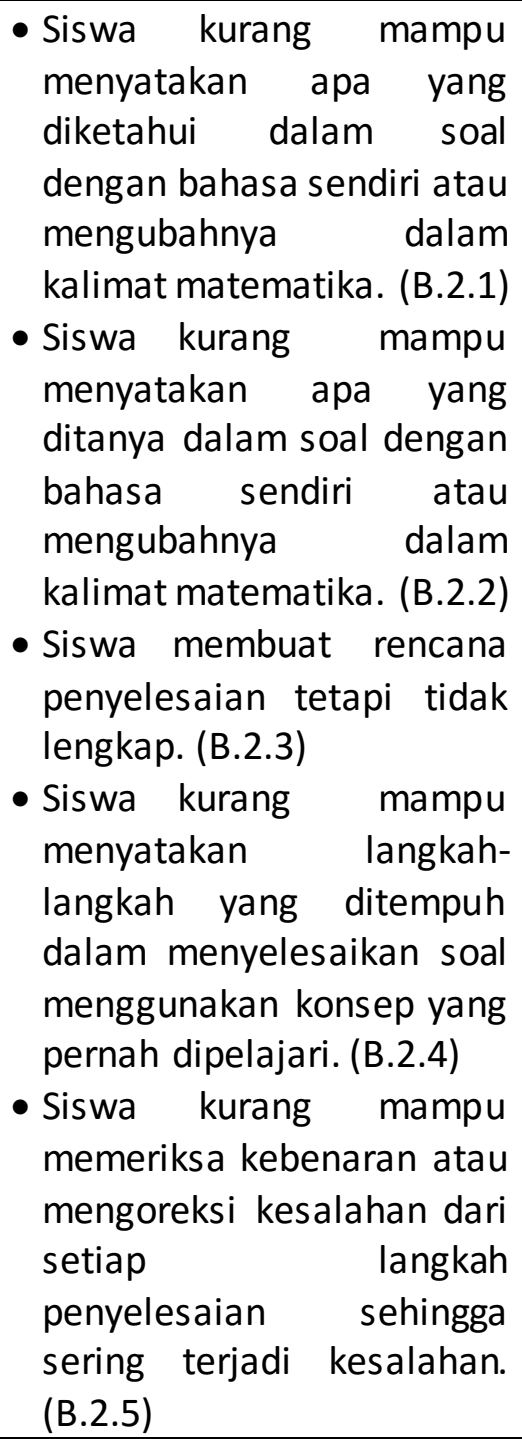 & $\begin{array}{l}\text { - Siswa tidak mampu } \\
\text { menyatakan apa yang } \\
\text { diketahui dalam soal } \\
\text { dengan bahasa sendiri } \\
\text { atau mengubahnya } \\
\text { dalam kalimat } \\
\text { matematika. (B.3.1) } \\
\text { - Siswa tidak mampu } \\
\text { menyatakan apa yang } \\
\text { ditanya dalam soal } \\
\text { dengan bahasa sendiri } \\
\text { atau mengubahnya } \\
\text { dalam kalimat } \\
\text { matematika. (B.3.2) } \\
\text { - Siswa tidak membuat } \\
\text { rencana penyelesaian } \\
\text { dengan lengkap. (B.3.3) } \\
\text { - Siswa tidak mampu } \\
\text { menyatakan langkah- } \\
\text { langkah yang ditempuh } \\
\text { dalam menyelesaikan } \\
\text { soal menggunakan } \\
\text { konsep yang pernah } \\
\text { dipelajari. (B.3.4) } \\
\text { - Siswa tidak memeriksa } \\
\text { atau mengoreksi } \\
\text { kembali penyelesaian } \\
\text { yang dibuat. (B.3.5) }\end{array}$ \\
\hline
\end{tabular}

(Retna, Mubarokah, \& Suhartatik, 2013)

Proses berpikir yang berbeda-beda juga terlihat pada siswa kelas X MAN 1 Bandar Lampung Khususnya X MIA 4. Berdasarkan hasil pengamatan prapenelitian yang diadakan pada tanggal 21 Januari 2016 di MAN 1 Bandar Lampung pada materi Sistem Persamaan Linear Dua Variabel (SPLDV), terlihat jelas bahwa bahwa proses berpikir siswa sangat beragam, hal ini terlihat dari hasil tes tertulis atau pengerjaan soal SPLDV dan wawancara yang dilakukan terhadap beberapa siswa setelah siswa selesai mengerjakan soal. Dari 30 siswa yang mengerjakan tes, 7 siswa mengerjakan soal sesuai dengan konsep yang diajarkan, 14 siswa mengerjakan soal sesuai dengan konsep namun belum sepenuhnya sehingga dicampur dengan intuisi, dan 9 siswa mengerjakan soal dengan tidak menggunakan konsep tetapi mengandalkan intuisi. Wawancara kemudian dilakukan kepada tiga siswa dari masing- 
masing tipe guna menggali informasi lebih jauh terkait dengan hal-hal yang melatar belakangi siswa dalam menyelesaikan soal.

Ketika proses berpikir untuk menemukan jawaban berlangsung, siswa akan mengalami berbagai permasalahan sebagai hambatan dalam memecahkan masalah, dan tidak semua siswa dapat melampauinya. Keberhasilan jawaban tersebut juga dipengaruhi oleh beberapa faktor sehingga menjadikan siswa tersebut sukses dalam memecahkan masalah. Faktor penentu kesuksesan yang banyak dibicarakan tentu saja seputar Intelegence Quotient, Emotional Quotient, dan Spiritual Quotient. Namun ada lagi faktor penentu kesuksesan yang belum banyak dibicarakan orang, yaitu Adversity Quotient yang diperkenalkan oleh Paul G. Stoltz, $A Q$ digunakan untuk menilai sejauh mana seseorang menghadapi masalah rumit dan penuh tantangan dan bahkan merubahnya menjadi sebuah peluang. Berkaitan dengan itu, dalam menghadapi masalah terdapat tiga tipe anak dalam $A Q$, yakni tipe quitters (mereka yang berhenti), yaitu kelompok orang yang kurang memiliki kemauan untuk menerima tantangan sehingga hidupnya sekedar untuk bertahan hidup. Tipe campers (mereka yang berkemah), yaitu kelompok orang yang memiliki kemauan menghadapi masalah akan tetapi mereka tetap tidak mengambil resiko terukur dan aman, sehingga menghentikan perjalanannya cukup sampai disini dan tipe climbers (mereka yang mendaki) yaitu kelompok orang yang memiliki keberanian dalam menghadapi masalah dan resiko sehingga pekerjaan mereka tuntas sesuai tujuannya (Stoltz, 2000).

Adversity Quotient memiliki empat dimensi yang masing-masing merupakan bagian dari respon seseorang dalam menghadapi masalah. Dimensi tersebut anatara lainfungsi control $\left(\mathrm{C} /\right.$ kendali), origin dan ownership ( $\mathrm{O}_{2} /$ asal-usul dan pengakuan), reach ( $\left.\mathrm{R} / \mathrm{jangkauan}\right)$ dan endurance ( $E$ /daya tahan). Makin besar nilai $A Q$, maka makin besar kecerdasannya dalam menghadapi kesulitan. Biasanya yang mempunya nilai tinggi, orang-orang yang berpengalaman atau pernah mengalami tingkat kesulitan yang tinggi tapi bisa bertahan hingga sukses. Paul G. Stoltz mengemukakan bahwa rumus pengukuran Adversity Quotient seseorang adalah $\mathrm{C}+\mathrm{O}_{2}+\mathrm{R}+\mathrm{E}=\mathrm{AQ}$ (Stoltz, 2000).

Berdasarkan uraian di atas, maka maka indikator yang digunakan dalam penelitian ini mengadaptasi dari 4 dimensi tersebut sebagai:

Tabel 2. Indikator Adversity Quotient

\section{Indikator}

(Dimensi Adversity Quotient: $\mathrm{CO}_{2}$ RE)

1. Control (Kendali) tingkat kendali yang dirasakan terhadap peristiwa yang menimbulkan kesulitan

2. Origin (asal usul) dan Ownership (pengakuan)

3. Reach (Jangkauan) sejauh mana kesulitan dianggap dapat menjangkau ke bagian-bagian lain dari kehidupan

Pengukuran Indikator

Kontrol diri siswa saat merasakan adanya kesulitan

Or: Pengakuan terhadap asal usul adanya kesulitan

Ow: Pengakuan terhadap terjadinya kesulitan Pengakuan siswa akan sejauh mana kesulitan dianggap dapat menjangkau ke bagian-bagian lain dari kehidupan 
4. Endurance (Daya Tahan)
Anggapan siswa akan berapa lama

kesulitan itu akan berlangsung dan

Berapa lamakah penyebab

kesulitan itu akan berlangsung

Selain proses berpikir setiap siswa yang berbeda-beda sebagai mana telah dijelaskan, menurut Stoltz, Adversity Quotient mempunyai pengaruh penting dalam keberhasilan seorang. Keberhasilan atau kegagalan siswa dalam belajar dapat ditunjukan melalui prestasi belajar yang telah dicapai. Kiriteria ketuntasan minimal untuk pelajaran matematika siswa Madrasah Aliyah Negeri (MAN) 1 Bandar Lampung adalah 75. Berdasarkan data hasil Nilai Semester Ganjil Matematika (Wajib) Kelas X MIA 4 MAN 1 Bandar Lampung Tahun 2015/2016 terlihat bahwa yang mendapatkan nilai $\geq 75$ hanya 5 siswa, nilai $60 \leq x<75$ adalah 10 siswa dan yang menndapatkan nilai $<60$ adalah 22 siswa. Berdasarkan data di atas penulis menyimpulkan bahwa tingkat pemecahan masalah masing-masing siswa berbeda-beda berdasarkan proses berpikir mereka yang juga berbeda-beda. Untuk itulah $A Q$ menjadi sedemikian penting dalam hidup seseorang. Pertama, $A Q$ menunjukkan seberapa baik kita dapat bertahan menghadapi kesulitan dan mengatasinya. Kedua, $A Q$ merupakan alat ukur yang dapat memprediksi siapa yang mampu mengatasi kesulitan dan siapa yang jauh. Perlu keyakinan akan potensi diri untuk menjadikan sukses.

Berdasarkan uraian latar belakang masalah diatas, penulis tertarik mengkaji secara lebih lanjut tentang "Proses Berpikir Siswa dalam Memecahkan Masalah Matematika Berdasarkan Langkah Bransford dan Stein Ditinjau dari Adversity Quotient pada Siswa kelas X MAN 1 Bandar Lampung Tahun 2015/2016." Tujuan penelitian ini adalah untuk mendeskripsikan proses berpikir siswa dari masing-masing tipe Adversity Quotient dalam memecahkan masalah matematika berdasarkan langkah-langkah Bransford dan Stein pada siswa kelas X MAN 1 Bandar Lampung Tahun 2015/2016.

\section{METODE PENELITIAN}

Penelitian ini merupakan penelitian deskriptif kualitatif. Subjek penelitian ditentukan melalui purposive sampling (Nurmasari, Kusmayadi, \& Riyadi, 2014), dan penelitian inidilakukan di kelas X MIA 4 MAN I Bandar Lampung dengan subjek berjumlah 6 siswa yang dibagi menjadi 3 kelompok. Kelompok pertama terdiri dari 2 siswa bertipe climbers, kelompok kedua terdiri dari 2 siswa bertipe campers, dan kelompok ketiga terdiri dari 2 siswa bertipe quitters. Untuk menentukan tipe Adversity Quotient (AQ) dari subjek yang akan dipilih, digunakan tes $A R P$. Teknik pengumpulan data pada penelitian ini menggunakan metode tes, metode wawancara tak terstruktur yang dilakukan kepada subjek yang telah terpilih dan metode dokumentasi. Teknik analisis data melalui reduksi data, penyajian data, dan penarikan kesimpulan (Moleong, 2011). Data hasil tes tertulis dianalisis berdasarkan indikator-indikator yang memenuhi proses berpikir konseptual, semikonseptual, dan komputasional. Teknik keabsahan data dilakukan dengan menggunakan triangulasi teknik (Sugiyono, 2014) yang membandingkan data hasil tes tertulis dan hasil wawancara terhadap subjek climbers, campers dan quitters. 


\section{HASIL PENELITIAN DAN PEMBAHASAN}

Subjek penelitian diambil berdasarkan pada hasil uji ARP. Adapun keenam siswa yang menjadi subjek dalam penelitian ini dapat dilihat pada Tabel 3:

Tabel 3. Daftar Nama Subjek Penelitian

\begin{tabular}{llcll}
\hline No. & \multicolumn{1}{c}{ Nama } & Inisial & Kelompok & Kode Subjek \\
\hline 1 & Ahmad Auliya Fadly & AF & Climbers & Subjek AF \\
2 & Faisal Nuril Qolbi & FN & Climbers & Subjek FN \\
3 & M. Dzaky Daradjat & MD & Campers & Subjek MD \\
4 & Qothratinnada & QT & Campers & Subjek QT \\
5 & Lilia Aftika & LA & Quitters & Subjek LA \\
6 & Shalsabilla Deyan Ayu Maharani & SD & Quitters & Subjek SD \\
\hline
\end{tabular}

Setelah keenam subjek terpilih, selanjutnya peneliti memberikan soal tes uraian kepada enam subjek penelitian. Subjek diminta mengerjakan soal tes uraian dengan teliti dalam waktu 30 menit. Untuk memperoleh data yang mendalam mengenai proses berpikir yang dilakukan siswa dalam menyelesaikan masalah matematika dilakukan wawancara pada keenam subjek. Setelah data hasil tes uraian dan hasil wawancara diperoleh, maka dilakukan analisis data pada hasil tes tertulis dan hasil wawancara.

\section{Proses Berpikir Subjek dengan Tipe Climbers dalam Memecahkan Masalah Berdasarkan} Langkah-langkah Bransford dan Stein

Berdasarkan hasil deskripsi dan analisis data di atas, dapat diketahui bahwa kedua subjek climbers yang terpilih berdasarkan tes $A R P$ adalah subjek AF dan Subjek FN. Kedua subjek cenderung melakukan proses berpikir yang sama. Berikut ini merupakan tabel tipe proses berpikir untuk subjek dengan tipe Adversity Quotient $(A Q)$ climbers:

Tabel 4. Tipe Proses Berpikir Subjek dengan Adversity Quotient Tipe Climbers

\begin{tabular}{|c|c|c|c|c|c|c|}
\hline Subjek & Soal & $\begin{array}{c}\text { Langkah- } \\
\text { langkah } \\
\text { Pemecahan } \\
\text { Masalah } \\
\text { Bransford } \\
\text { dan Stein } \\
\end{array}$ & $\begin{array}{l}\text { Indikator } \\
\text { Proses } \\
\text { Berpikir }\end{array}$ & $\begin{array}{l}\text { Proses Berpikir } \\
\text { Tiap Langkah }\end{array}$ & $\begin{array}{c}\text { Kesimpulan } \\
\text { Proses } \\
\text { Berpikir } \\
\text { Soal }\end{array}$ & $\begin{array}{c}\text { Kesimpulan } \\
\text { Akhir }\end{array}$ \\
\hline \multirow[t]{10}{*}{$\mathrm{AF}$} & 1 & 1 & B.1.1 & Konseptual & Konseptual & \multirow{10}{*}{ Konseptual } \\
\hline & & 2 & B.1.2 & Konseptual & & \\
\hline & & 3 & B.1.3 & Konseptual & & \\
\hline & & 4 & B.1.4 & Konseptual & & \\
\hline & & 5 & B.1.5 & Konseptual & & \\
\hline & 2 & 1 & B.1.1 & Konseptual & Konseptual & \\
\hline & & 2 & B.1.2 & Konseptual & & \\
\hline & & 3 & B.1.3 & Konseptual & & \\
\hline & & 4 & B.1.4 & Konseptual & & \\
\hline & & 5 & B.1.5 & Konseptual & & \\
\hline FN & 1 & 1 & B.2.1 & Semikonseptual & & Konseptual \\
\hline
\end{tabular}




\begin{tabular}{lllll}
\hline & 2 & B.1.2 & Konseptual & Semikonsep \\
& 3 & B.2.3 & Semikonseptual & tual \\
& 4 & B.2.4 & Semikonseptual & \\
5 & 5 & B.1.5 & Konseptual & \\
& 1 & B.1.1 & Konseptual & Konseptual \\
2 & B.1.2 & Konseptual & \\
& 3 & B.1.3 & Konseptual & \\
& 4 & B.1.4 & Konseptual & \\
& 5 & B.1.5 & Konseptual & \\
\hline
\end{tabular}

Berdasarkan Tabel 4, terlihat bahwa kedua subjek memiliki tipe proses berpikir yang sama yaitu konseptual. Meskipun pada bagian kesimpulan proses berpikir soal, subjek FN memiliki proses berpikir semikonseptual dan konseptual, namun pada kesimpulan akhir subjek FN bertipe proses berpikir konseptual. Kesimpulan ini berpedoman pada aturan dalam Bab III terutama pada bagian e, maka dapat disimpulkan bahwa subjek dengan $A Q$ tipe climbers cenderung memiliki proses berpikir konseptual. Proses berpikir konseptual adalah cara berpikir yang selalu menyelesaikan masalah dengan menggunakan konsep yang telah dimiliki berdasarkan hasil pelajarannya selama ini (Retna, Mubarokah, \& Suhartatik, 2013).

Proses Berpikir Subjek dengan Tipe Campers dalam Memecahkan Masalah Berdasarkan Langkah-langkah Bransford dan Stein

Berdasarkan hasil deskripsi dan analisis data di atas, dapat diketahui bahwa kedua subjek campers yang terpilih berdasarkan tes ARP adalah subjek MD dan Subjek QT. Kedua subjek cenderung melakukan proses berpikir yang sama. Berikut ini merupakan tabel tipe proses berpikir untuk subjek dengan tipe Adversity Quotient $(A Q)$ campers:

Tabel 5. Tipe Proses Berpikir Subjek dengan Adversity Quotient Tipe Campers

\begin{tabular}{|c|c|c|c|c|c|c|}
\hline Subjek & Soal & $\begin{array}{c}\text { Langkah- } \\
\text { langkah } \\
\text { Pemecaha } \\
\text { n Masalah } \\
\text { Bransford } \\
\text { dan Stein }\end{array}$ & $\begin{array}{c}\text { Indikator } \\
\text { Proses } \\
\text { Berpikir }\end{array}$ & $\begin{array}{l}\text { Proses Berpikir } \\
\text { Tiap Langkah }\end{array}$ & $\begin{array}{c}\text { Kesimpulan } \\
\text { Proses Berpikir } \\
\text { Soal }\end{array}$ & $\begin{array}{c}\text { Kesimpulan } \\
\text { Akhir }\end{array}$ \\
\hline \multirow[t]{10}{*}{$\mathrm{MD}$} & \multirow[t]{5}{*}{1} & 1 & B.2.1 & Semikonseptual & \multirow[t]{5}{*}{ Semikonseptual } & \multirow{10}{*}{$\begin{array}{l}\text { Semi- } \\
\text { konseptual }\end{array}$} \\
\hline & & 2 & B.2.2 & Semikonseptual & & \\
\hline & & 3 & B.2.3 & Semikonseptual & & \\
\hline & & 4 & B.2.4 & Semikonseptual & & \\
\hline & & 5 & B.1.5 & Konseptual & & \\
\hline & \multirow[t]{5}{*}{2} & 1 & B.1.1 & Konseptual & \multirow[t]{5}{*}{ Semikonseptual } & \\
\hline & & 2 & B.1.2 & Konseptual & & \\
\hline & & 3 & B.2.3 & Semikonseptual & & \\
\hline & & 4 & B.2.4 & Semikonseptual & & \\
\hline & & 5 & B.2.5 & Semikonseptual & & \\
\hline \multirow[t]{3}{*}{ QT } & \multirow[t]{3}{*}{1} & 1 & B.2.1 & Semikonseptual & \multirow[t]{3}{*}{ Semikonseptual } & \multirow{3}{*}{$\begin{array}{l}\text { Semi- } \\
\text { konseptual }\end{array}$} \\
\hline & & 2 & B.1.2 & Konseptual & & \\
\hline & & 3 & B.2.3 & Semikonseptual & & \\
\hline
\end{tabular}




\begin{tabular}{lllll}
\hline & 4 & B.2.4 & Semikonseptual & \\
& 5 & B.3.5 & Komputasional & \\
& 1 & B.1.1 & Konseptual & Semikonseptual \\
& 2 & B.1.2 & Konseptual & \\
& 3 & B.2.3 & Semikonseptual & \\
& 4 & B.2.4 & Semikonseptual & \\
& 5 & B.3.5 & Komputasional & \\
\hline
\end{tabular}

Berdasarkan Tabel 5, terlihat bahwa kedua subjek memiliki tipe proses berpikir yang sama yaitu semikonseptual. Berpedoman pada aturan dalam Bab III terutama, maka dapat disimpulkan bahwa subjek dengan $A Q$ tipe campers cenderung memiliki proses berpikir semikonseptual. Proses berpikir semikonseptual adalah proses berpikir yang dalam menyelesaikan suatu masalah cenderung menggunakan konsep tetapi mungkin karena pemahamannya terhadap konsep tersebut belum sepenuhnya lengkap maka penyelesaiannya dicampur dengan cara penyelesaian yang menggunakan intuisi (Retna, Mubarokah, \& Suhartatik, 2013).

Proses Berpikir Subjek dengan Tipe Quitters dalam Memecahkan Masalah Berdasarkan Langkah-langkah Bransford dan Stein

Berdasarkan hasil deskripsi dan analisis data di atas, dapat diketahui bahwa kedua subjek quitters yang terpilih berdasarkan tes $A R P$ adalah subjek LA dan Subjek SD. Kedua subjek cenderung melakukan proses berpikir yang sama, namun, dalam mengidentifikasi masalah (identify problem) respon kedua subjek berbeda pada setiap soal. Berikut ini merupakan tabel tipe proses berpikir untuk subjek dengan Adversity Quotient (AQ) tipe climbers:

Tabel 6. Tipe Proses Berpikir Subjek dengan Adversity Quotient Tipe Quitters

\begin{tabular}{|c|c|c|c|c|c|c|}
\hline Subjek & Soal & $\begin{array}{l}\text { Langkah- } \\
\text { langkah } \\
\text { Pemecahan } \\
\text { Masalah } \\
\text { Bransford } \\
\text { dan Stein }\end{array}$ & $\begin{array}{c}\text { Indikator } \\
\text { Proses } \\
\text { Berpikir }\end{array}$ & $\begin{array}{l}\text { Proses Berpikir } \\
\text { Tiap Langkah }\end{array}$ & $\begin{array}{l}\text { Kesimpulan } \\
\text { Proses } \\
\text { Berpikir Soal }\end{array}$ & $\begin{array}{c}\text { Kesimpulan } \\
\text { Akhir }\end{array}$ \\
\hline \multirow[t]{10}{*}{ LA } & 1 & 1 & B.1.1 & Konseptual & Komputasional & \\
\hline & & 2 & B.1.2 & Konseptual & & \\
\hline & & 3 & B.3.3 & Komputasional & & \\
\hline & & 4 & B.3.4 & Komputasional & & \\
\hline & & 5 & B.3.5 & Komputasional & & Kompu- \\
\hline & 2 & 1 & B.2.1 & Semikonseptual & Komputasional & tasional \\
\hline & & 2 & B.2.2 & Semikonseptual & & \\
\hline & & 3 & B.3.3 & Komputasional & & \\
\hline & & 4 & B.3.4 & Komputasional & & \\
\hline & & 5 & B.3.5 & Komputasional & & \\
\hline \multirow[t]{2}{*}{ SD } & 1 & 1 & B.2.1 & Semikonseptual & Komputasional & Kompu- \\
\hline & & 2 & B.1.2 & Konseptual & & tasional \\
\hline
\end{tabular}




\begin{tabular}{|c|c|c|c|c|}
\hline \multirow{8}{*}{2} & 3 & B.3.3 & Komputasional & \multirow{8}{*}{ Komputasional } \\
\hline & 4 & B.3.4 & Komputasional & \\
\hline & 5 & B.3.5 & Komputasional & \\
\hline & 1 & B.3.1 & Komputasional & \\
\hline & 2 & B.1.2 & Konseptual & \\
\hline & 3 & B.3.3 & Komputasional & \\
\hline & 4 & B.3.4 & Komputasional & \\
\hline & 5 & B.2.5 & Semikonseptual & \\
\hline
\end{tabular}

Berdasarkan Tabel 6, terlihat bahwa kedua subjek memiliki tipe proses berpikir yang sama yaitu komputasional. Berpedoman pada aturan dalam Bab III terutama, maka dapat disimpulkan bahwa subjek dengan $A Q$ tipe quitters cenderung memiliki proses berpikir komputasional. Proses berpikir komputasional adalah proses berpikir yang pada umumnya menyelesaikan suatu soal tidak menggunakan konsep tetapi lebih mengandalkan intuisi (Retna, Mubarokah, \& Suhartatik, 2013).

Berdasarkan pembahasan yang telah dilakukan, terlihat perbedaan pada proses berpikir subjek antara subjek tipe climbers, campers dan quitters. Subjek dengan tipe climbersdalam menyelesaikan masalah matematika, subjek memiliki keyakinan yang tinggi bahwa setiap masalah pasti bisa terselesaikan, mereka tidak menyerah dan tidak berputus asa sesulit apa pun masalah yang sedang dihadapi sampai mereka mencapai kesuksesan atau mendapat jawaban yang benar. Subjek campers dalam menyelesaikan masalah matematika, subjekmengalami kesulitan maka subjek tersebut akan tetap berusaha untuk bisa menyelesaikan masalahnya, sedangkan subjek quitters pada saat mengalami kesulitan maka siswa tersebut mudah menyerah dan tidak mau berusaha untuk bisa menyelesaikannya. Meskipun ada usaha, usahanya pun sangat kecil. Hal ini sesuai dengan teori Paul G. Sroltz dalam bukunya "Adversity Quotient: Mengubah Hambatan Manjadi Peluang" bahwa $A Q$ membedakan climbers dengan campers dan quitters. Ketika situasi semakin sulit, Quitters akan menyerah dan campers akan berkemah, sementara climbers bertahan dan terus mendaki (Stoltz, 2000). Adanya proses berpikir yang berbeda antara siswa tipe climbers, campers dan quitter ini tentunya akan berdampak pada prestasi belajar matematika yang berbeda pula antara ketiganya.

\section{SIMPULAN DAN SARAN}

Berdasarkan rumusan masalah, hasil penelitian yang telah diuji keabsahannya menggunakan triangulasi teknik dan pembahasan, maka pada penelitian ini diperoleh simpulan sebagai berikut:

1. Kelompok subjek dengan Adversity Quotient $(A Q)$ tipe climbers cenderung memiliki tipe proses berpikir konseptual dalam menyelesaikan masalah. Subjek AF dalam menyelesaikan masalah memiliki proses berpikir konseptual dan subjek FN memiliki proses berpikir konseptual.

2. Kelompok subjek dengan Adversity Quotient $(A Q)$ tipe campers cenderung memiliki tipe proses berpikir semikonseptual. Subjek MD dalam menyelesaikan masalah memiliki proses berpikir semikonseptual dan subjek QT memiliki proses berpikir semikonseptual. 
3. Kelompok subjek dengan Adversity Quotient $(A Q)$ tipe quitters cenderung memiliki tipe proses berpikir komputasional. Subjek LA dalam menyelesaikan masalah memiliki proses berpikir komputasional dan subjek SD memiliki proses berpikir komputasional.

\section{DAFTAR PUSTAKA}

Ahmadi, H. A. (2009). Psikologi Umum. Jakarta: Rineka Cipta.

Ahmadi, H. A., \& Widodo Supriyono. (2013). Psikologi Belajar (III ed.). Jakarta: Rineka Cipta.

D, Z. (1998). Tipe Berpikir Sisw Kelas II SMPN Pekanbaru dalam Menyelesaikan Soal-soal Perbandingan Berbalik Nilai. Surabaya: Tesis Sarjana Pendidikan Pascasarjana UNESA.

Hartono, Y. (2014). Matematika: Strategi Pemecahan Masalah (1st ed.). Yogyakarta: Graha IImu.

J, B., \& Stein, B. (1993). The IDEAL Problem Solver: A Guide for Improving Thinking, Learning, and Creativity (2nd ed.). New York: W.H. Freeman.

Moleong, L. J. (2011). Metodologi Penelitian Kualitatif (XXIX ed.). Bandung: PT Remaja Rosdakarya.

Nurmasari, N., Kusmayadi, T. A., \& Riyadi. (2014). Analisis Berpikir Kreatif Siswa Dalam Menyelesaikan Masalah Matematika pada Materi Peluang Ditinjau dari Gender Siswa Kelas XI IPA SMA Negeri 1 Kota Banjararu Kalimantan Selatan. Jurnal Elektronik Pembelajaran Matematika UNS.

Retna, M., Mubarokah, L., \& Suhartatik. (2013). Proses Berpikir Siswa dalam Menyelesaikan Soal Cerita Ditinjau Berdasarkan Kemampuan Matematika. Jurnal Pendidikan Matematika STKIP PGTI Sidoarjo, 1(2), 71-82.

Stoltz, P. G. (2000). Adversity Quetient: Mengubah Hambatan Menjadi Peluang (1 ed.). (T.Hermaya, Penerj.) Jakarta: Gramedia.

Sugiyono. (2014). Penelitian Kuantitatif, Kualitatif dan R\&D (XX ed.). Bandung: Alfabeta.

Suryabrata, S. (2013). Psikologi Pendidikan (XIX ed.). Jakarta: Rajawali Pers.

Susiana, E. (2010). IDEAL Problem Solving dalam Pembelajaran. Jurnal Matematika kreatifinovatif, 1(2), 73-82. 